\title{
งารสารว̄ศวกรSแศาสกร์
}

\section{การปรับปรุงกำลังการผลิตของสายการผลิตชิ้นส่วนเบาะที่ นั่งรถยนต์ด้วยแนวคิดระบบการผลิตแบบโตโยต้า}

\section{สุจินดา ศรัณย์ประชา}

ภาควิชาวิศวกรรมอุตสาหการ คณะวิศวกรรมศาสตร์ จุฬาาลงกรณ์มหาวิทยาลัย กรุงเทพฯ 10330 ประเทศไทย อีเมล์: s.sujinda@hotmail.com

บทคัดย่อ บทความนี้รายงานการปรับปรุงกำลังการผลิตของสายการผลิตชิ้นสวนเบาะที่นั่งรถยนต์ซึ่งไม่เพียงพอต่อยอด สั่งซื้อที่เพิ่มขึ้นเกือบเท่าตัว ทางผู้บริหารจึงมีแนวคิดที่จะแก้ปัญหาด้วยวิธีการเพิ่มจำนวนชั่วโมงการทำงานและขณะเดียวกัน ก็ต้องการปรับปรุงประสิทธิภาพของการทำงานโดยการนำแนวคิดของระบบการผลิตแบบโตโยต้ามาประยุกต์ใช้ใดยปรับ เปลี่ยนกระบวนการผลิตแบบเป็นงวดให้เป็นแบบการไหลทีละชิ้นเพื่อมุ่งเน้นการลดต้นทุนที่เกินความจำเป็นและการกำจัด ความสูญเปล่าที่เกิดขึ้นในกระบวนการ การดำเนินการปรับปรุงเริ่มจากการศึกษากระบวนการผลิตโดยใช้เครื่องมือของ การศึกษาวิธีการทำงาน การศึกษาเวลา การจัดทำผังของสถานที่ทำงาน และการจัดทำแผนภูมิกระบวนการผลิต แล้ว นำมาใช้วิเคราะห์และระบุความสูญเปล่า 7 ประการ ที่อาจมีในกระบวนการทำงานจากนั้นได้จัดทำแผนภูมิพาเรโตเพื่อ คัดเลือกกระบวนการทำงานที่เป็นปัญหามาปรับปรุงแล้วใช้ Why-Why Analysis วิเคราะห์หาสาเหตุของแต่ละปัญหา เหล่านั้น เพื่อนำไปใช้ในการปรับปรุงประสิทธิภาพการทำงานด้วยหลักการ ECRS วิธีการทำงานที่ปรับปรุงถูกนำไปใช้เป็น การทำงานมาตรฐานโดยใช้การจัดสมดุลของสายการผลิตแล้วปรับปรุงแผนผังสถานที่การทำงานให้สอดคล้องกับระบบการ ผลิตแบบใหม่ เพื่อให้มีกำลังการผลิตเพียงพอต่ออัตราผลิตที่ต้องการและปรับเพิ่มชั่วโมงการผลิตเป็น 2 กะ แต่ผลจากการ ปรับปรุงการใช้แรงงานในสายการผลิตที่ดีกว่าเดิมประมาณ 23 เปอร์เซ็นต์ ทำให้ลดการใช้พนักงานลง 6 คน จากที่เคย วางแผนไว้ 26 คนและประหยัดการใช้พื้นที่ในกระบวนการผลิตลงเพื่อนำไปใช้ในการขยายสายการผลิตอื่นได้ 103 ตาราง เมตร คิดเป็น 22.85 เปอร์เซ็นต์ จากที่เคยต้องใช้ 452 ตารางเมตร

คำสืบค้น : ระบบการผลิตแบบโตโยต้า, ความสูญเปล่า 7 ประการ, การจัดสมดุลสายการผลิต

วารสารวิศวกรรมศาสตร์ (ISSN: 1906-3636) ปีที่ 5 ฉบับที่ 1

วันที่ส่ง 25 มีนาคม 2556

วันที่ตอบรับ 28 พฤษภาคม 2556

วันที่ตีพิมพ์ 29 มกราคม 2557

Online at http://www.ej.eng.chula.ac.th/

DOI:10.4186/ejth.2013.5.1.11 


\section{งารสารว̄ศวกรSแศาสกร์}

\section{Capacity Improvement of Car-Seat Part Production Line with Toyota Production System Concept}

\section{Sujinda Saranpracha}

Department of Industrial Engineering, Faculty of Engineering, Chulalongkorn University, Bangkok 10330, Thailand

E-mail: s.sujinda@hotmail.com

Abstract. This paper explains the capacity improvement of car-seat part production that is insufficient to meet the demand which has nearly doubled. The management intends to increase working hours and also improve work efficiency by applying the concept of Toyota Production System by changing the production process from batch production to one-piece flowline in order to reduce cost and eliminate wastes in the process. The improvement process starts from studying the production process with the tools of Work Study, Time Study, Work Place Layout and Work Process Flow Charts. The results are used to analyse and identify the Seven Wastes which may exist in the work process. A Pareto diagram is then created in order to select significant efficiency problems that should be concentrated on for improvement. The Why-Why Analysis is then applied to each of the selected problems to analyse its real causes. After that, the ECRS principle is used to improve work efficiency. The improved working procedures are used as standard work methods in Line Balancing process. The working hours must be increased to two shifts in order to have sufficient capacity for the required production rate. However, the significant one is $23.1 \%$ improvement in labor efficiency, which reduces the manpower requirement by six from the originally planned of 26 . The production area is reduced from $452 \mathrm{~m}^{2}$ so that it can be used for the expansion of another production line by $103 \mathrm{~m}^{2}$, or $22.8 \%$.

Keywords: Toyota production system, Muda 7, line balancing.

Engineering Journal (ISSN: 1906-3636) Volume 5 Issue 1

Received 25 March 2013

Accepted 28 May 2013

Published 29 January 2014

Online at http://www.ej.eng.chula.ac.th/

DOI:10.4186/ejth.2013.5.1.11 


\section{1. บทนำ}

โรงงานที่ศึกษาเป็นผู้ผลิตชิ้นส่วนภายในรถยนต์ ผลิตภัณฑ์ที่เป็นกรณีศึกษาเป็นชิ้นส่วนที่อยู่ในห้องโดยสารข้างในตัวถัง รถยนต์ คือ ชิ้นส่วนเบาะที่นั่งรถยนต์ประกอบด้วย หมอนรองศีรษะด้านหน้า หมอนรองศีรษะด้านหลัง หมอนรองศีรษะตรง กลางด้านหลัง ที่วางแขน และเสาข้างเบาะหลัง ปัจจุบันสายการผลิตเป็นการผลิตแบบเป็นงวด (Batch) ซึ่งไม่สามารถผลิต ได้ตามความต้องการของลูกค้า เนื่องจากการใช้ทรัพยากรอย่างไม่มีประสิทธิภาพ ทำให้เกิดการสูญเสียพื้นที่ เวลา สินค้าคง คลัง และจำนวนพนักงานที่เกินความจำเป็นต่อสายการผลิต

ทางโรงงานได้รับการพยากรณ์ยอดสั่งซื้อจากลูกค้าล่วงหน้า 2 ปี เมื่อเทียบกับปัจจุบันยอดสั่งซื้อหมอนรองศีรษะสูงขึ้น ถึง 6,273 ชุดต่อคันรถ คิดเป็น 57.93 เปอร์เซ็นต์ และยอดสั่งซื้อที่วางแขนและเสาข้างเบาะหลังสูงขึ้นถึง 2,356 ชุดต่อคันรถ คิดเป็น 141.16 เปอร์เซ็นต์ ปัจจุบันทั้งสองกระบวนการผลิตมีเพียง 1 กะ เท่านั้น และมีการทำงานล่วงเวลาสำหรับการผลิต หมอนรองศีรษะ จากยอดสั่งซื้อที่สูงขึ้นการผลิตเพียง 1 กะ นั้นไม่เพียงพอต่อความต้องการที่จะเพิ่มขึ้น ดังนั้นทางโรงงานมี นโยบายที่จะเตรียมรับมือในยอดสั่งซื้อที่เพิ่มขึ้นสูงสุด โดยจะเพิ่มการผลิตเป็น 2 กะ ทำให้เกิดต้นทุนในการผลิตเพิ่มขึ้นกว่า 2 เท่า อีกด้วย

จากปัญหาที่กล่าวมาข้างต้น ผู้บริหารของโรงงานมีความต้องการที่จะเตรียมความพร้อมในด้านกำลังการผลิตพร้อมกับ การลดต้นทุน ดังนั้นจึงเสนอแนวทางการประยุกต์ใช้ระบบการผลิตแบบโตโยต้าในการปรับปรุงการผลิตแบบไหลทีละชิ้นและ การจัดสมดุลสายการผลิตใหม่ ลดความสูญเปล่าที่เกิดขึ้นในกระบวนการผลิต ปรับปรุงผังสายการผลิต และปรับปรุงขั้นตอน การทำงานใหม่ เพื่อทำให้ประสิทธิภาพในการทำงานเพิ่มขึ้น ซึ่งจะส่งผลทำให้ต้นทุนในการที่จะผลิต 2 กะ ลดลงด้วย

\section{2. ทฤษฎีที่นำมาใช้}

ระบบการผลิตแบบโตโยต้า [1] เป็นเครื่องมือในการจัดการกระบวนการผลิตมีเป้าหมายในการลดต้นทุนโดยการกำจัดความ สูญเปล่า ผลิตตามคำสั่งซื้อเท่านั้น ผลิตของที่มีคุณภาพดี ผลิตของที่มีต้นทุนราคาถูก สร้างระบบการผลิตให้มีความยืดหยุ่น เพื่อตอบสนองต่อความเปลี่ยนแปลงได้ เรียกว่า ระบบทันเวลาพอดีหรือ Just in time การวิจัยได้นำแนวคิดการลดต้นทุน ด้วย 3 หลักการพื้นฐาน ประกอบด้วย

1. การปรับเปลี่ยนจากการที่มีสินค้าคงคลังระหว่างกระบวนการผลิตเนื่องจากวิธีผลิตเป็น batch ที่แต่ละหน่วยงานให้เป็น แบบการดึงจากกระบวนการถัดไป

2. ลดระยะทางขนส่งระหว่างกระบวนการเพื่อให้เหมาะสมกับการผลิตแบบไหลต่อเนื่องหรือไหลทีละชิ้น

3. ทำสายการผลิตให้มีความยืดหยุ่นกับการผลิตในปริมาณที่จำเป็นตามรอบเวลาในการผลิต (Takt Time) ที่เหมาะสมกับ อัตราการผลิต

สายการผลิตเป็นพื้นฐานในระบบการผลิต [2] ที่มักพบปัญหาในการแจกจ่ายปริมาณงานของแต่ละสถานีที่ไม่ต่อเนื่อง ในการทำงานเกิดความสิ้นเปลืองของแรงงานและวัสดุอุปกรณ์ ทำให้ต้องมีการการลดเวลา การจัดสมดุลสายการผลิต และ การจัดลำดับงานก่อนหลัง [3] เพื่อให้มีประสิทธิภาพในการผลิตของแต่ละกระบวนการต้องปรับเรียบจำนวนงานและเวลา ของแต่ละสถานีงานให้เท่าๆ กันภายใต้รอบเวลาในการผลิต (Takt time) [4] ซึ่งเป็นเครื่องมือในการควบคุมเป้าหมายในการ ผลิตเพื่อให้ระบบการผลิตสามารถทำงานได้ตรงตามรอบเวลาในการผลิต (Takt time) นั้นมาจากการคำนวณหาเวลาจาก ความต้องการของลูกค้า 
งานวิจัยได้เพิ่มผลิตภาพโดยการกำจัดความสูญเปล่า 7 ประการ ซึ่งได้แก่ การผลิตที่มากเกินไป การรอคอย การขนส่ง กระบวนการที่ไม่เหมาะสม การมีวัสดุหรือสินค้าคงคลังที่ไม่จำเป็น การผลิตของเสียและแก้ไขงานเสีย และการเคลื่อนไหวที่ ไม่เหมาะสม [5] และงานวิจัยได้ประยุกต์ใช้ระบบการผลิตแบบโตโยต้าในการกำจัดความสูญเปล่า ปรับปรุงกระบวนการ ผลิตให้เป็นแบบการไหลแบบต่อเนื่อง จัดสมดุลการทำงานใหม่ และจัดทำมาตรฐานงานใหม่ ในการปรับปรุงสามารถเพิ่ม ประสิทธิภาพการผลิต ลดพื้นที่ และลดวัสดุคงคลัง [6] การปรับปรุงกระบวนการผลิตให้เป็นแบบการไหลอย่างเนื่องจะต้อง ออกแบบให้การเคลื่อนที่ของสิ่งของ การเคลื่อนไหวของพนักงาน และการถ่ายทอดข้อมูลเป็นไปได้อย่างสะดวก สามารถ ดำเนินไปได้อย่างราบรื่นและคล่องตัว [7] ซึ่งจะจัดทำแผนภูมิกระบวนการผลิตเพื่อดูปัญหาแต่ละขั้นตอนและหาสาเหตุโดย ใช้การตั้งคำถาม Why-Why Analysis แล้วใช้หลักการ ECRS (การกำจัด, การรวมกัน, การจัดใหม่, ทำให้ง่ายขึ้น) ในการ ดำเนินการปรับปรุงสายการผลิต [8]

การวิจัยได้นำแนวคิดการลดต้นทุนด้วย 3 หลักการพื้นฐานเข้าไปปรับปรุงสายการผลิตและวิเคราะห์สาเหตุของปัญหา โดยใช้เครื่องมือการกำจัดความสูญเปล่า 7 ประการ และปรับปรุงสายการผลิตด้วยหลักการ ECRS เพื่อให้สายการผลิตมี ประสิทธิภาพเพิ่มมากขึ้นพร้อมกับสามารถลดต้นทุนในการผลิต

\section{3. ข้อมูลเบื้องต้นของโรงงานกรณีศึกษา}

โรงงานกรณีศึกษาดำเนินธุรกิจเป็นผู้ผลิตชิ้นส่วนภายในรถยนต์ ผลิตภัณฑ์ที่เป็นกรณีศึกษาเป็นชิ้นส่วนเบาะที่นั่งรถยนต์ ซึ่ง ประกอบด้วย หมอนรองศีรษะด้านหน้า หมอนรองศีรษะตรงกลางด้านหลัง ที่วางแขนและเสาข้างเบาะหลัง ลักษณะการ สั่งซื้อชิ้นงานจากลูกค้าเป็นรูปแบบของชุดต่อคันรถ เช่น หมอนรองศีรษะ 1 ชุด ประกอบด้วย หมอนรองศีรษะด้านหน้า 2 ชิ้น หมอนรองศีรษะตรงกลางด้านหลัง 2 ชิ้น และหมอนรองศีรษะตรงกลางด้านหลัง 1 ชิ้น ส่วนที่วางแขนและเสาข้างเบาะหลัง 1 ชุด ประกอบด้วย ที่วางแขน 1 ชิ้น และเสาข้างเบาะหลัง 2 ชิ้น

กระบวนการผลิตหมอนรองศีรษะด้านหน้า ด้านหลัง และตรงกลางด้านหลัง คือ นำผ้า PVC มาเย็บขึ้นรูป ประกอบชิ้น ส่วนย่อย ฉีดโฟมเข้าไปในผ้าหุ้ม ตัดแต่ง ทำความสะอาด และตรวจสอบสภาพผื้นผิว สำหรับกระบวนการผลิตที่วางแขนและ เสาข้างเบาะหลัง คือ นำผ้า PVC มาเย็บขึ้นรูป ฉีดโฟมขึ้นรูป ตัดแต่ง ใส่ผ้าหุ้มกับโฟมที่ฉีดขึ้นรูป ประกอบชิ้นส่วนย่อย และ ตรวจสอบสภาพผื้นผิว

เดิมทางโรงงานมียอดการผลิตหมอนรองศีรษะและการผลิตที่วางแขนและเสาข้างเบาะหลังต่อเดือนเท่ากับ 3,972 ชุด ต่อคันรถ และ 975 ชุดต่อคันรถ โดยใช้วันทำงานทั้งหมด 22 วัน มีเพียง 1 กะ เวลาในการทำงาน 450 นาที หรือ 27,000 วินาที สำหรับการผลิตหมอนรองศีรษะมีการทำงานล่วงเวลาเพิ่มอีก 120 นาที เท่ากับ 32,400 วินาที่ แต่เมื่อลูกค้ายังมีความ ต้องการมากขึ้น โดยมียอดการสั่งซื้อหมอนรองศีรษะโดยเฉลี่ยมากถึง 5,507 ชุดต่อคันรถต่อเดือน และสูงถึง 6,273 ชุดต่อ คันรถในบางเดือนดังรูปที่ 1 และยอดการสั่งซื้อที่วางแขนและเสาข้างเบาะหลังโดยเฉลี่ยมากถึง 1,759 ชุดต่อคันรถต่อเดือน และสูงถึง 2,356 ชุดต่อคันรถในบางเดือน รูปที่ 2 จึงทำให้โรงงานต้องเพิ่มกำลังการผลิตเพื่อรองรับความต้องการของลูกค้า ให้ได้ 


\section{4. แนวทางและขั้นตอนการดำเนินงาน}

สำหรับขั้นตอนการดำเนินงานวิจัยนี้ แบ่งออกเป็น 4 ขั้นตอน ประกอบด้วย 1. การศึกษาข้อมูลเบื้องต้นของโรงงาน กรณีศึกษา 2. การเก็บข้อมูลสภาพปัญหา 3. การวิเคราะห์สาเหตุของปัญหา 4. การวางแผนและดำเนินการปรับปรุงแก้ไข ปัญหา โดยมีรายละเอียดการดำเนินการในแต่ละขั้นตอนดังต่อไปนี้

\section{1. การศึกษาข้อมูลเบื้องต้นของโรงงานกรณีศึกษา}

1. การรวบรวมข้อมูลด้านนโยบายจากผู้บริหารในการปรับปรุงประสิทธิภาพของสายการผลิตเพื่อดำเนินการตามนโยบาย นี้ประกอบด้วย

1.1. รูปแบบของระบบการผลิตที่พึงประสงค์ คือ การผลิตแบบต่อเนื่องหรือแบบไหลทีละชิ้นตามหลักการระบบการผลิต แบบโตโยต้า

1.2. การปรังปรุงต้องรองรับกับยอดการสั่งซื้อที่สูงที่สุดโดยปราศจากการทำงานล่วงเวลา เพื่อที่จะรองรับการผลิตเพิ่ม ในอนาคตเมื่อยอดการสั่งซื้อเพิ่มขึ้นจากการพยากรณ์เดิม

1.3. ต้องลดทุนของสายการผลิตที่จะเพิ่มขึ้นกว่า 2 เท่า เช่น ค่าจ้างแรงงาน ค่าจ้างการทำงานล่วงเวลา ค่า สาธารณูปโภค ลดการใช้เครื่องมือและอุปกรณ์ที่ไม่จำเป็น

2. ศึกษาความสามารถในการผลิต (Process Capability) ปัจจุบันโดยคำนวณจากชั่วโมงการทำงานที่กำหนดดังตารางที่ 1 ซึ่งปัจจุบันมีวันทำงานเท่ากับ 22 วันต่อเดือน วันละ 8 ชั่วโมงต่อ 1 กะ กับรอบเวลาในการผลิต (Takt Time) ปัจจุบัน เพื่อให้รู้ความสามารถในการผลิตปัจจุบันว่าสามารถรองรับการผลิตที่เพิ่มขึ้นได้หรือไม่

ตารางที่ 1 ข้อมูลเวลาที่ใช้ในการทำงานของสายการผลิต

\begin{tabular}{lc}
\hline ข้อมูล & เวลา \\
\hline เวลาทำงาน $7.30-16.30$ & 480 นาที \\
เวลาประชุมตอนเช้า & 5 นาที \\
เวลาพักช่วงเช้า & 10 นาที \\
เวลาพักช่วงบ่าย & 10 นาที \\
เวลาทำ 5 ส ก่อนเลิกงาน & 5 นาที \\
\hline เวลาที่ใช้ทำงานจริงต่อเดือน (x60 วินาที $)$ & 594,000 วินาที \\
\hline
\end{tabular}

การหาความสามารถในการผลิตดังสมการที่ (1)

$$
\text { ความสามารถในการผลิต = เวลาที่ใช้ทำงานจริงต่อเดือน / รอบเวลาในการผลิต }
$$

จากสมการที่ (1) คำนวณหาความสามารถในการผลิตหมอนรองศีรษะได้เท่ากับ 3,839 ชิ้น ต่อเดือน และความสามารถ ในการผลิตที่วางแขนและเสาข้างเบาะหลังได้เท่ากับ 1,260 ชิ้น ต่อเดือน แล้วนำข้อมูลเปรียบเทียบกับยอดการสั่งซื้อจาก ลูกค้า

3. ศึกษายอดการสั่งซื้อจากลูกค้า (Demand) ที่สูงสุดของการพยากรณ์ล่วงหน้า 2 ปี เพื่อนำข้อมูลมาวางแผนการปรับปรุง ความสามารถในการผลิต (Process Capability) ให้สามารถผลิตชิ้นงานได้ตามยอดการสั่งซื้อที่สูงสุด 


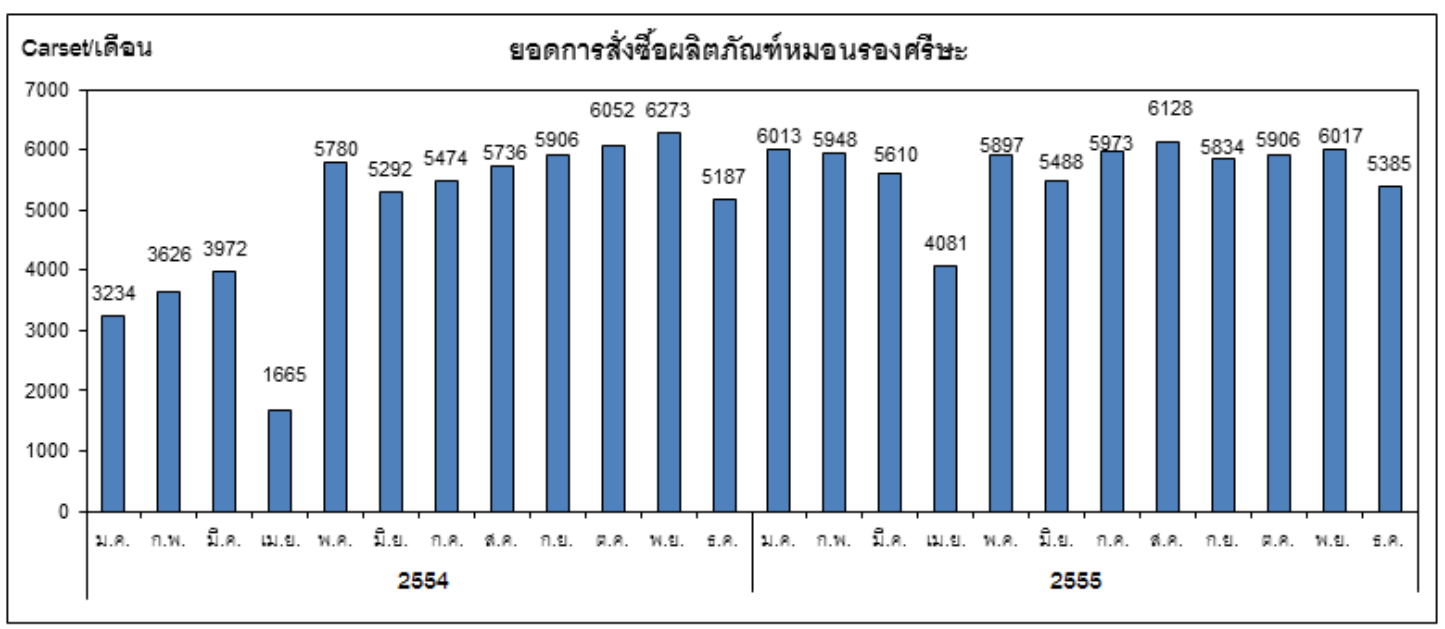

รูปที่ 1 แผนภูมิแสดงยอดการสั่งซื้อของหมอนรองศีรษะตั้งแต่เดือนมกราคม 2554 จนถึงเดือนธันวาคม 2555

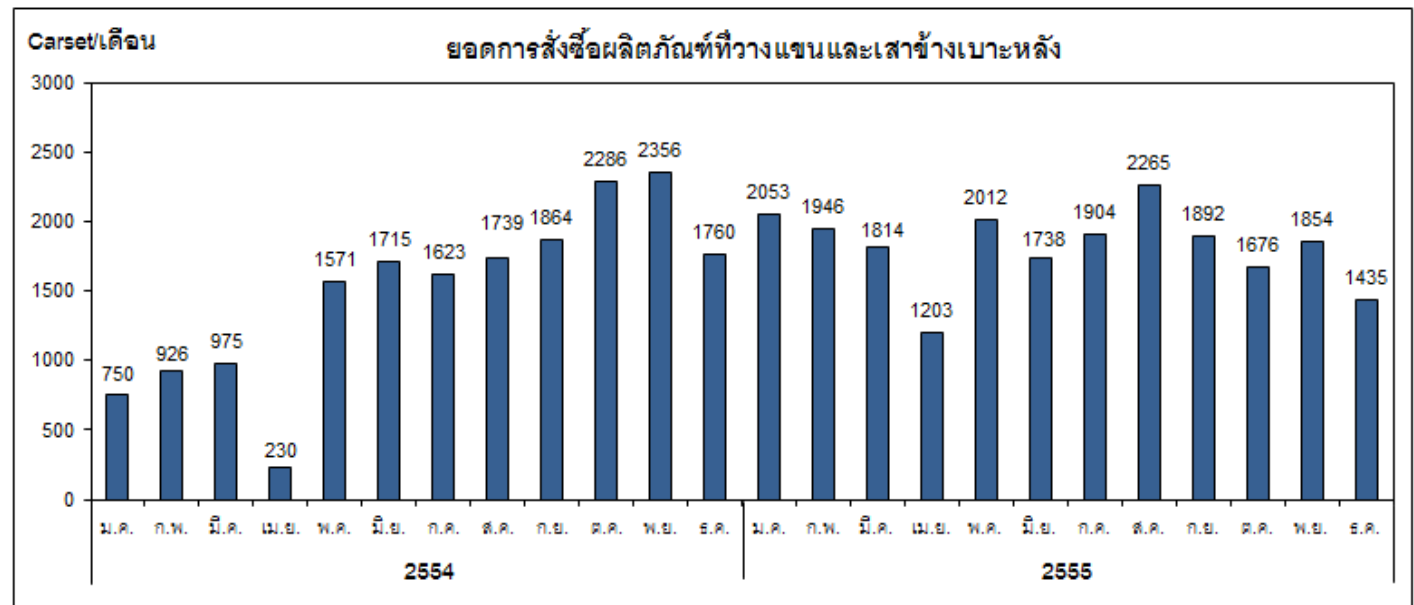

รูปที่ 2 แผนภูมิแสดงยอดการสั่งซื้อของที่วางแขนและเสาข้างเบาะหลังตั้งแต่เดือนมกราคม 2554 จนถึงเดือนธันวาคม 2555

จากการศึกษายอดการสั่งซื้อที่สูงสุดของการพยากรณ์ล่วงหน้า 2 ปี ของหมอนรองศีรษะสูงถึง 6,273 ชุดต่อคันรถ (Carset) ดังรูปที่ 1 และของที่วางแขนและเสาข้างเบาะหลังสูงถึง 2,356 ชุดต่อคันรถ (Carset) ดังรูปที่ 2 เมื่อเปรียบเทียบกับ ความสามารถในการผลิตจึงทำให้โรงงานต้องเพิ่มกำลังการผลิตเพื่อรองรับกับความต้องการของลูกค้าให้ได้

\section{2. การเก็บข้อมูลสภาพปัญหา}

1. สำรวจสภาพปัญหาอย่างเป็นขั้นตอนโดยใช้หลักการการศึกษาวิธีการทำงาน (Work Study) เข้าไปศึกษากระบวนการ ผลิตที่หน้างานจริงพร้อมทั้งถ่ายภาพวีดีโอและจดบันทึกปัญหาต่างๆ โดยระบุเป็นความสูญเปล่า 7 ประการ ที่พบ เช่น วิธีการทำงานที่ไม่เหมาะสม วิธีการขนส่งชิ้นงานระหว่างกระบวนการที่มากเกินไป การรอคอยงาน การวางกระบวนการที่ไม่ 
เหมาะสม เป็นต้น เพื่อนำมาจัดทำผังของสถานที่ทำงานและแผนภาพกระบวนการมาตรฐานแล้วใช้วิเคราะห์หาปัญหาที่ แท้จริง

2. นำข้อมูลที่ได้จากการสำรวจมาสร้างผังของสถานที่ทำงานเพื่อให้เห็นภาพรวมของสายการผลิต เช่น ตำแหน่งการวาง กระบวนการ เครื่องจักร คน และอุปกรณ์ต่างๆ รวมถึงเส้นทางการขนส่งที่เกิดขึ้นในสายการผลิต เพื่อนำข้อมูลมา ประกอบการวิเคราะห์หาความสูญเปล่าที่เกิดขึ้นในสายการผลิต

3. สร้างแผนภาพกระบวนการมาตรฐาน (Standard Work Process Chart) ดังรูปที่ 3 และ 4 เพื่อศึกษาการเคลื่อนไหว ของพนักงาน การไหลของชิ้นงานระหว่างกระบวนการเป็นไปแบบต่อเนื่องหรือไม่ เพื่อนำข้อมูลมาประกอบการวิเคราะห์หา ความสูญเปล่าที่เกิดขึ้นในสายการผลิต

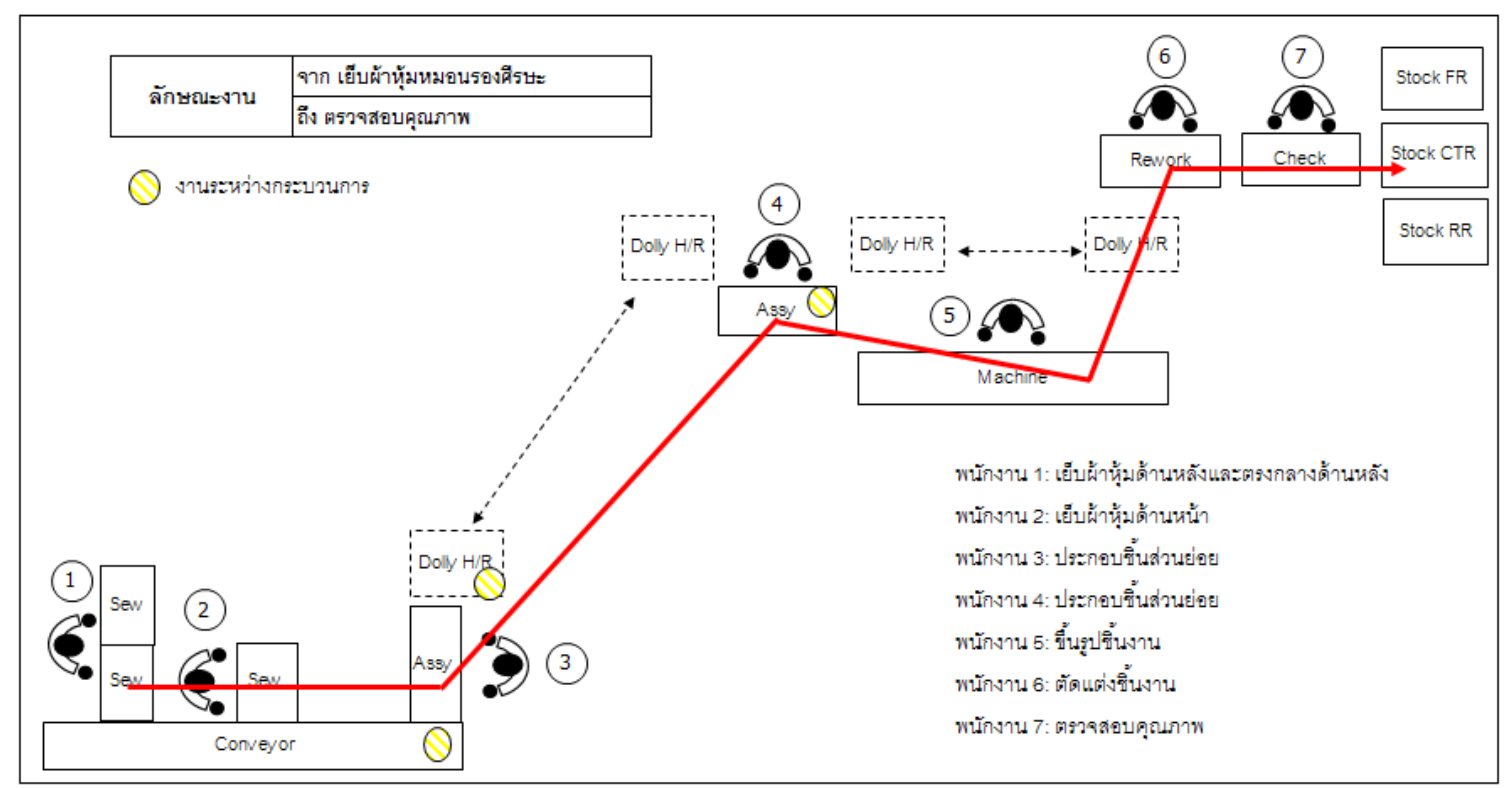

รูปที่ 3 แผนภาพกระบวนการมาตรฐานของกระบวนการผลิตหมอนรองศีรษะก่อนการปรับปรุง

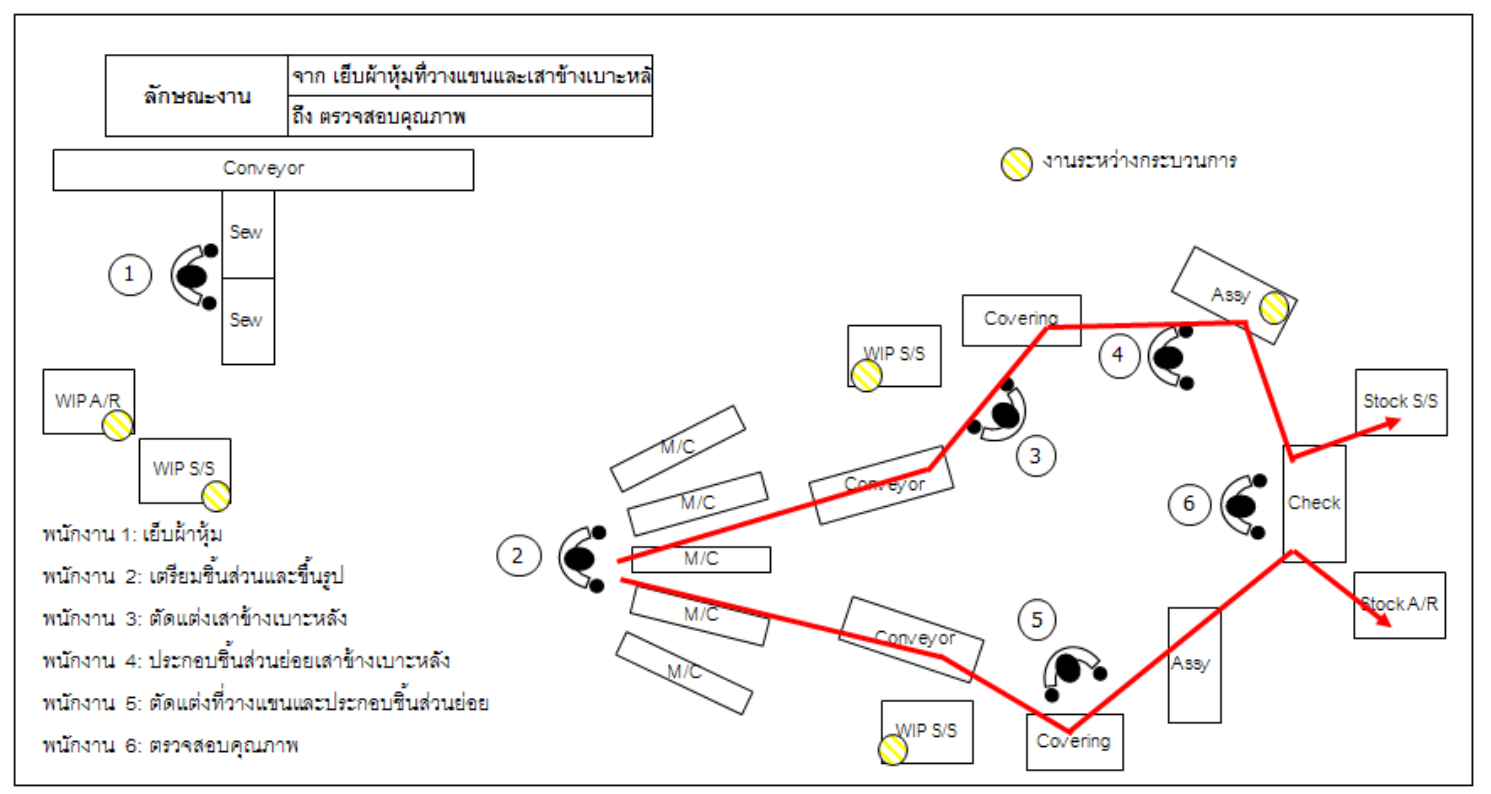

รูปที่ 4 แผนภาพกระบวนการมาตรฐานของกระบวนการผลิตที่วางแขนและเสาข้างเบาะหลังก่อนการปรับปรุง 
4. สร้างแบบบันทึกเพื่อเก็บข้อมูลขั้นตอนและเวลาของการทำงานแต่ละกระบวนการโดยการเก็บข้อมูล 10 รอบเวลาในการ ทำงาน (Ten Time Check) ตามหลักการระบบการผลิตแบบโตโยต้า (Toyota Production System) แล้วนำไปสร้างแผนภูมิ กระบวนการผลิต (Flow Process Chart) ทุกกระบวนการเพื่อนำไปวิเคราะห์ระบุความสูญเปล่า 7 ประการ และเวลาที่ สูญเสียในการผลิต จากการเก็บข้อมูลรอบเวลาในการทำงานของแต่ละกระบวนการสามารถนำมาคำนวณหาประสิทธิภาพ ของกระบวนการผลิตปัจจุบัน ดังสมการที่ (2)

$$
\text { ประสิทธิภาพของกระบวนการผลิต }=\left\{1-\frac{(\mathrm{nTc}-\mathrm{Twc})}{\mathrm{nTc}}\right\} \times 100 \%
$$

เมื่อ Tc คือ รอบเวลาในการทำงาน (Cycle Time); Twc คือ รอบเวลาในการทำงานรวมให้เสร็จเป็นชิ้นงานแต่ละหน่วย; $n$ คือ จำนวนกระบวนการ

จากรูปที่ 5 และ 6 คำนวณหาประสิทธิภาพของกระบวนการผลิตหมอนรองศีรษะเท่ากับ 78.7 เปอร์เซ็นต์ และ กระบวนการผลิตที่วางแขนและเสาข้างเบาะหลังเท่ากับ 75.2 เปอร์เซ็นต์ เพื่อดูประสิทธิภาพในการผลิตและใช้เปรียบเทียบ ก่อนและหลังการปรับปรุง

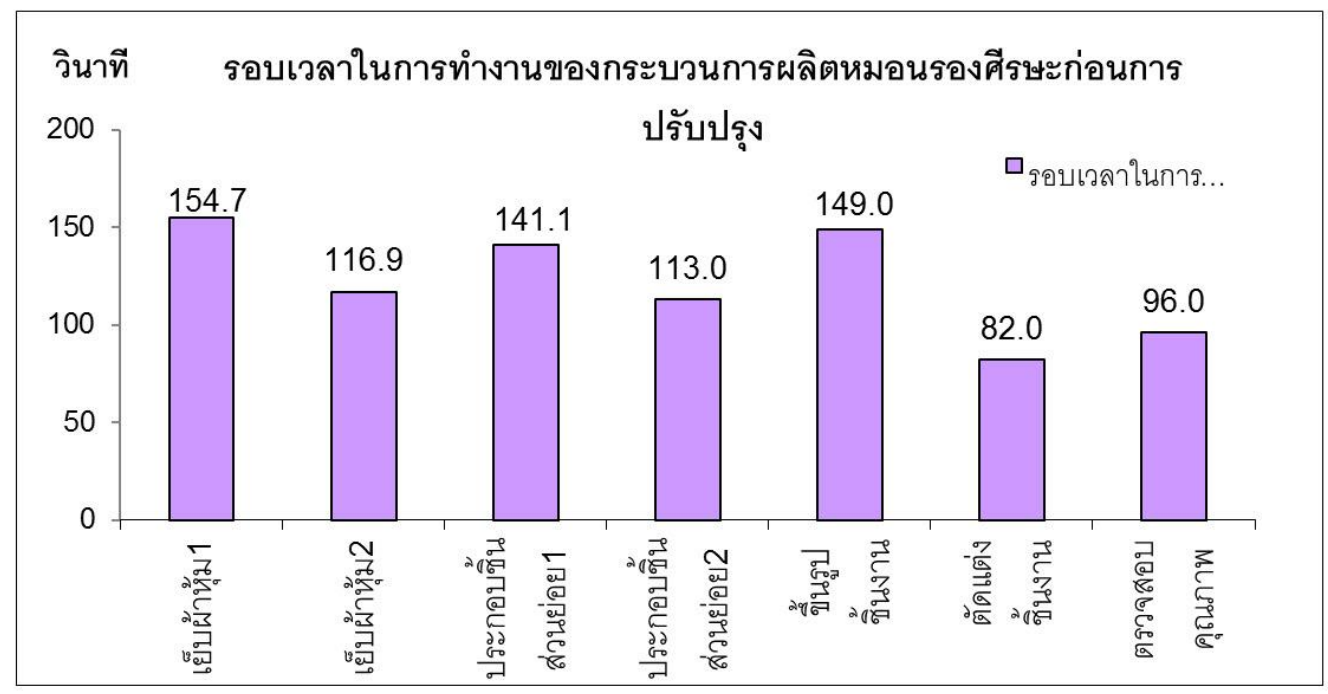

รูปที่ 5 รอบเวลาในการทำงานของกระบวนการผลิตหมอนรองศีรษะก่อนการปรับปรุง

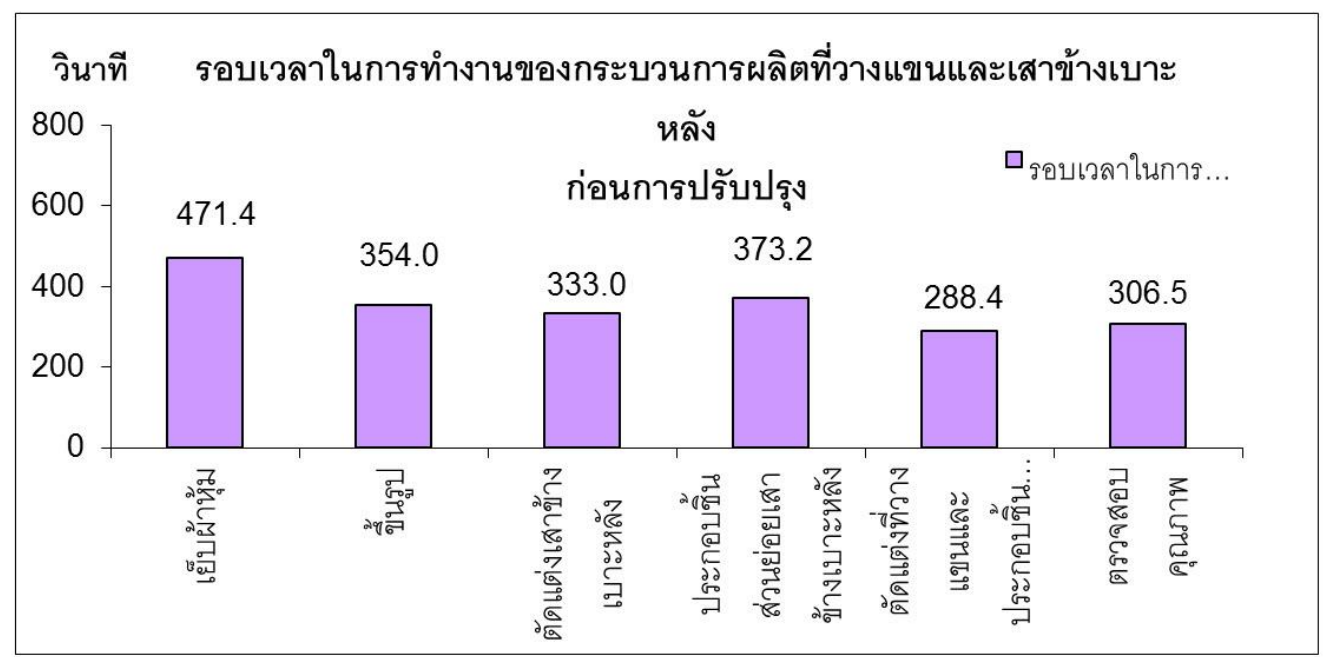

รูปที่ 6 รอบเวลาในการทำงานของกระบวนการผลิตที่วางแขนและเสาข้างเบาะหลังก่อนการปรับปรุง 
จากนั้นยกตัวอย่างการสร้างแผนภูมิกระบวนการผลิตของกระบวนการประกอบชิ้นส่วนย่อย 2 ของการผลิตหมอนรอง ศีรษะ มีกระบวนการทำงานดังนี้ นำชิ้นงานจากบรรจุภัณฑ์มาใส้ก้านเหล็กเข้าไปในผ้าหุ้มหลังจากนั้นวางชิ้นงานลงบน รถเข็นชิ้นงาน

จากการสร้างแผนภูมิกระบวนการผลิตของกระบวนการประกอบชิ้นส่วนย่อย 2 พบว่าเมื่อพิจารณาขั้นตอนการทำงานมี สัดส่วนของงานที่ก่อให้เกิดมูลค่าเป็นเวลา 36 วินาที คิดเป็น 32 เปอร์เซ็นต์ ของเวลาทั้งหมด สัดส่วนของขั้นตอนที่ไม่ ก่อให้เกิดมูลค่าซึ่งประกอบไปด้วยเวลารองานจากกระบวนการก่อนหน้า (41.8 วินาที) คิดเป็น 37 เปอร์เซ็นต์ จัดรูปร่างของ ตะเข็บ (18.6 วินาที) คิดเป็น 16 เปอร์เซ็นต์ เอางานไปวางบนรถเข็น (10.8 วินาที) คิดเป็น 10 เปอร์เซ็นต์ และอื่นๆ คิดเป็น 5 เปอร์เซ็นต์ ของเวลาทั้งหมด แล้วนำข้อมูลเวลาของงานที่ไม่เกิดคุณค่าหรือเกิดความสูญเปล่ามาจัดทำแผนภูมิพาเรโตเพื่อ คัดเลือกกระบวนการทำงานไปวิเคราะห์หาสาเหตุต่อไป

5. นำข้อมูลที่เก็บได้ทั้งหมดมาจัดทำแผนภูมิพาเรโต (Pareto Chart) เพื่อคัดเลือกกระบวนการทำงานที่เป็นปัญหา ประสิทธิภาพที่สำคัญที่จะมุ่งเน้นการปรับปรุงโดยพิจารณาเลือกกระบวนการทำงานด้วยหลักการของโรงงานนำเปอร์เซ็นต์ รวม 2 ใน 3 หรือ 70 เปอร์เซ็นต์รวม ของกระบวนการที่เกิดความสูญเปล่า จากนั้นจึงนำไปสูการวิเคราะห์หาสาเหตุหลักของ ปัญหา

จากแผนภูมิพาเรโตรูปที่ 7 แสดงเปอร์เซ็นต์ความสูญเปล่าแต่ละกระบวนการเมื่อเปรียบเทียบกับรอบเวลาในการทำงาน จะวิเคราะห์หาสาเหตุของความสูญเปล่า 3 กระบวนการ คิดเป็นเปอร์เซ็นต์รวมเท่ากับ 76 เปอร์เซ็นต์ ตามนโยบายของ โรงงานที่กล่าวไว้ข้างต้น ซึ่งประกอบด้วยกระบวนการประกอบชิ้นส่วนย่อย 2 กระบวนการประกอบชิ้นส่วนย่อย 1 และ กระบวนการตัดแต่งชิ้นงาน แล้วจึงใช้หลักการ Why-Why Analysis ในการตั้งคำถามเพื่อหาสาเหตุของความสูญเปล่า

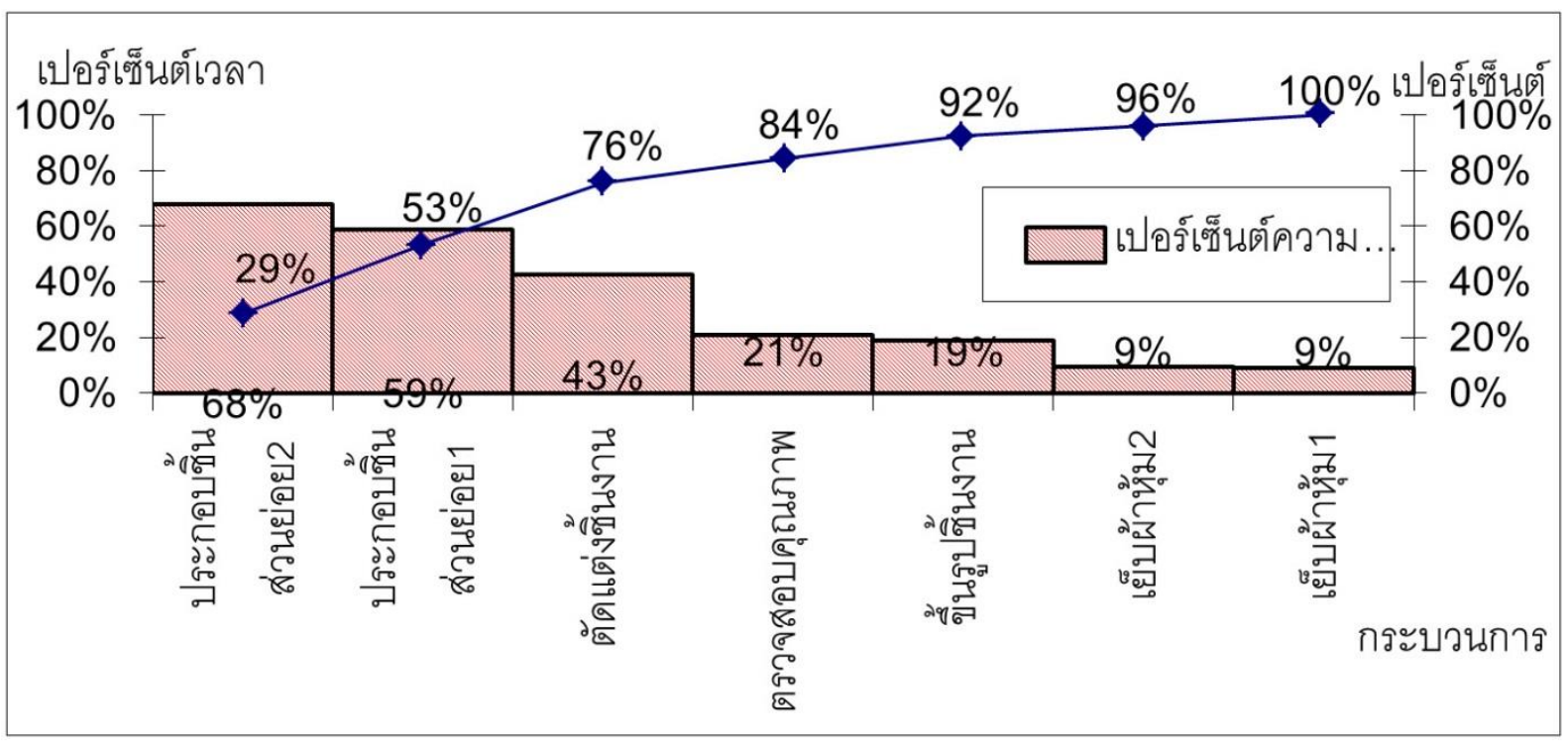

รูปที่ 7 แผนภูมิพาเรโตแสดงความสูญเปล่าแต่ละกระบวนการของกระบวนการผลิตหมอนรองศีรษะก่อนการปรับปรุง 
ตารางที่ 2 ตัวอย่างแผนภูมิกระบวนการผลิตแสดงขั้นตอนการทำงานของกระบวนการประกอบชิ้นส่วนย่อย 2

\begin{tabular}{|c|c|c|c|}
\hline ขั้นตอนการทำงาน & $\begin{array}{l}\text { เวลา } \\
\text { (วินาที) }\end{array}$ & สัญลักษณ์ & $\begin{array}{l}\text { ประเภท } \\
\text { ของงาน }\end{array}$ \\
\hline 1.หยิบ $\mathrm{FR}$ ชิ้นที่1 มาวางที่โต๊ะ & 1.0 & & V.A. \\
\hline 2.จัดรูปร่างของตะเข็บ $F R$ ชิ้นที่1 & 5.4 & & N.V.A. \\
\hline 3.หยิบก้านเหล็ก $\mathrm{FR}$ ชิ้นที่1 & 1.1 & & V.A. \\
\hline 4.ใสก้านเหล็กเข้ากับ $F R$ ชิ้นที่1 & 4.8 & & V.A. \\
\hline 5.เอาFR ชิ้นที่1 วางบนรถเข็น & 2.3 & & N.V.A. \\
\hline 6.หยิบ $F R$ ชิ้นที่2 มาวางที่โต๊ะ & 1.1 & & V.A. \\
\hline 7.จัดรูปร่างของตะเข็บ $F R$ ชิ้นที่2 & 3.2 & & N.V.A. \\
\hline 8.หยิบก้านเหล็ก $F R$ ชิ้นที่2 & 1.3 & & V.A. \\
\hline 9.ใสก้านเหล็ก เข้ากับ $F R$ ชิ้นที่2 & 5.0 & & V.A. \\
\hline 10.เอาFR ชิ้นที่2 วางบนรถเข็น & 2.0 & & N.V.A. \\
\hline 11.หยิบ $R R$ ชิ้นที่1 มาวางที่โต๊ะ & 1.1 & & V.A. \\
\hline 12.จัดรูปร่างของตะเข็บ $R R$ ชิ้นที่ 1 & 2.3 & & N.V.A. \\
\hline 13.หยิบก้านเหล็ก $R R$ ชิ้นที่1 & 1.2 & & V.A. \\
\hline 14.ใส่านเหล็กเข้ากับ $R R$ ชิ้นที่1 & 4.7 & & V.A. \\
\hline 15.เอาRR ชิ้นที่1 วางบนรถเข็น & 2.2 & & N.V.A. \\
\hline 16.หยิบ $R R$ ชิ้นที่2 มาวางที่โต๊ะ & 1.0 & & V.A. \\
\hline 17.จัดรูปร่างของตะเข็บ $R R$ ชิ้นที่2 & 2.9 & & N.V.A. \\
\hline 18.หยิบก้านเหล็ก $R R$ ชิ้นที่2 & 1.4 & & V.A. \\
\hline 19.ใส่ก้านเหล็กเข้ากับ RR ชิ้นที่2 & 5.2 & & V.A. \\
\hline 20.เอาRR ชิ้นที่2 วางบนรถเข็น & 2.0 & & N.V.A. \\
\hline 21.หยิบ CTR มาวางที่โต๊ะ & 1.0 & & V.A. \\
\hline 22.จัดรูปร่างของตะเข็บ CTR & 4.8 & & N.V.A. \\
\hline 23.หยิบก้านเหล็ก CTR & 1.1 & & V.A. \\
\hline 24.ใส่ก้านเหล็กเข้ากับ CTR & 5.1 & & V.A. \\
\hline
\end{tabular}


ตารางที่ 2 ตัวอย่างแผนภูมิกระบวนการผลิตแสดงขั้นตอนการทำงานของกระบวนการประกอบชิ้นส่วนย่อย 2 (ต่อ)

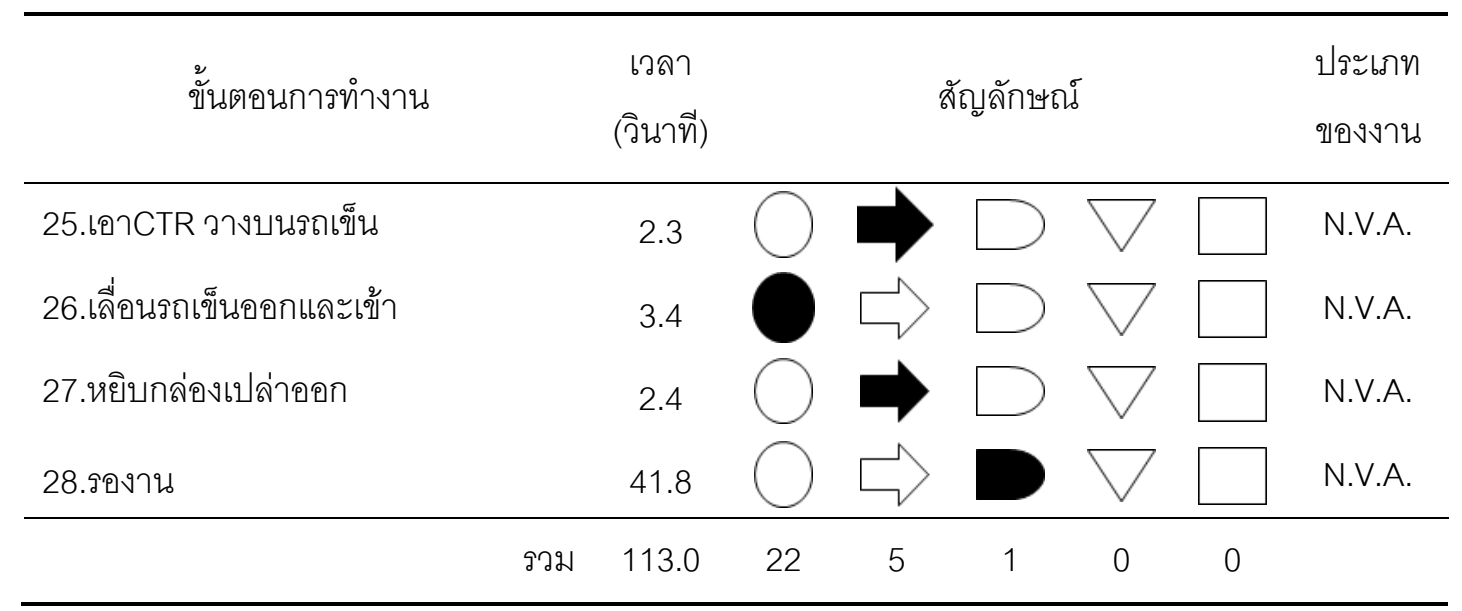

จากแผนภูมิพาเรโตรูปที่ 8 แสดงเปอร์เซ็นต์ความสูญเปล่าแต่ละกระบวนการเมื่อเปรียบเทียบกับรอบเวลาในการทำงาน จะวิเคราะห์หาสาเหตุของความสูญเปล่า 4 กระบวนการ คิดเป็นเปอร์เซ็นต์รวมเท่ากับ 77 เปอร์เซ็นต์ ตามนโยบายของ โรงงานที่กล่าวไว้ข้างต้น ซึ่งประกอบด้วยกระบวนการประกอบชิ้นส่วนย่อยเสาข้างเบาะหลัง กระบวนการตัดแต่งเสาข้าง เบาะหลัง กระบวนการตัดแต่งที่วางแขนและประกอบชิ้นส่วนย่อย และกระบวนการตรวจสอบคุณภาพ แล้วจึงใช้หลักการ Why-Why Analysis ในการตั้งคำถามเพื่อหาสาเหตุของความสูญเปล่า

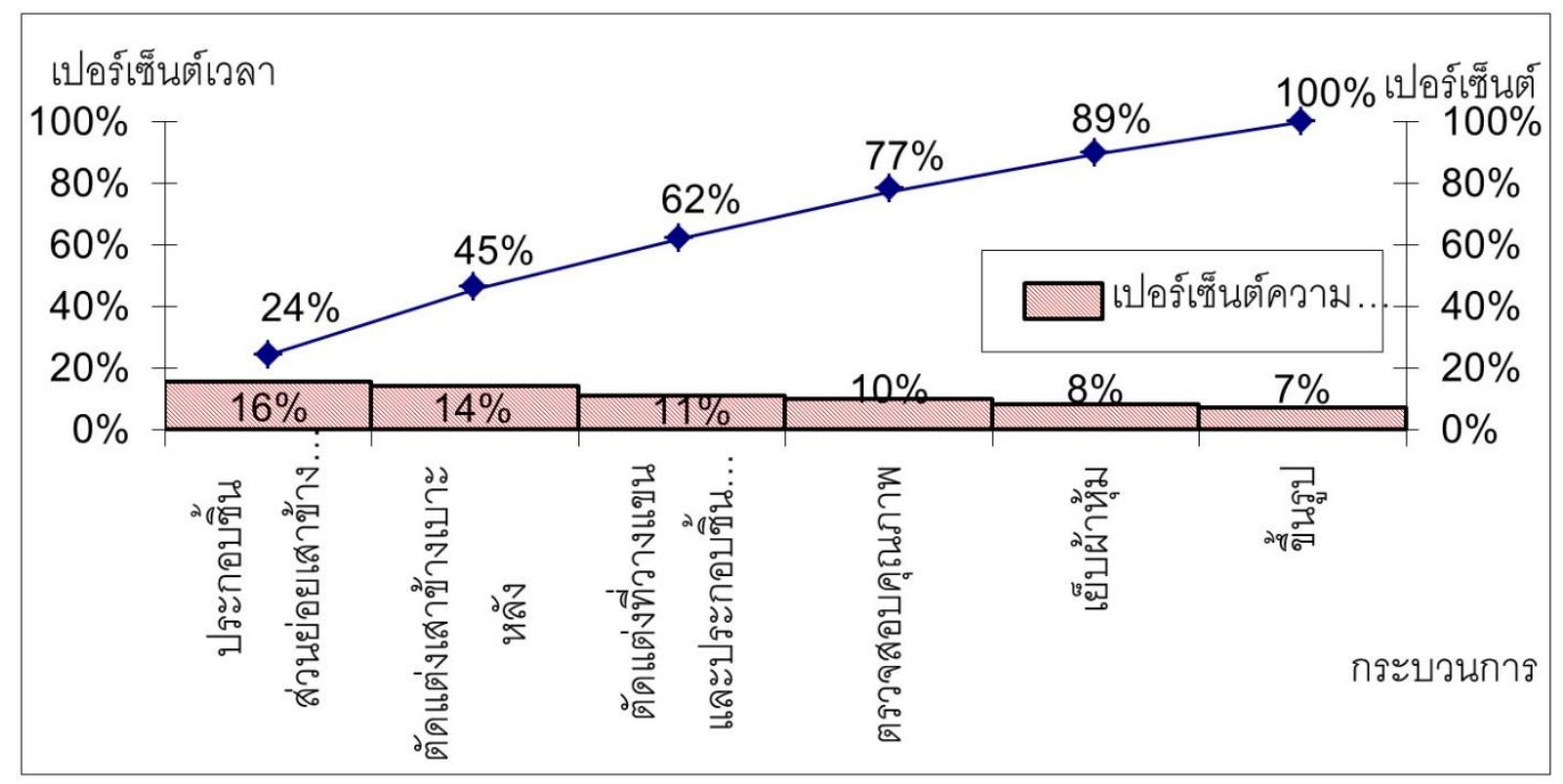

รูปที่ 8 แผนภูมิพาเรโตแสดงความสูญเปล่าแต่ละกระบวนการของกระบวนการผลิตที่วางแขนและเสาข้างเบาะหลังก่อน การปรับปรุง 


\section{3. การวิเคราะห์สาเหตุของปัญหา}

1. เข้าร่วมประชุมกับที่มงานเพื่อระดมสมอง (Brainstorming) สรุปสภาพปัญหาปัจจุบันของกระบวนการผลิตซึ่งพิจารณา จากแผนภูมิกระบวนการผลิต (Flow Process Chart) และนำปัญหาหลักที่เกิดขึ้นมาวิเคราะห์หาสาเหตุที่เกิดเวลาของความ สูญเปล่า โดยแบ่งการวิเคราะห์ออกเป็นแต่ละกระบวนการผลิต

ยกตัวอย่างเช่น จากแผนภูมิพาเรโตรูปที่ 7 จะเห็นได้ว่ากระบวนการประกอบชิ้นส่วนย่อย2 เกิดความสูญเปล่ามากที่สุด ดังนั้นนำข้อมูลปัญหาหลักที่ได้จากการพิจารณาแผนภูมิกระบวนการผลิตดังตารางที่ 2 มาวิเคราะห์หาสาเหตุของปัญหา ได้แก่ ขั้นตอนการรองานจากกระบวนการก่อนหน้า (41.8 วินาที่) คิดเป็น 37 เปอร์เซ็นต์ ของเวลาทั้งหมด

2. วิเคราะห์หาสาเหตุที่ทำให้เกิดเวลาของความสูญเปล่าในกระบวนการผลิตเพื่อให้ทราบสาเหตุของปัญหาที่แท้จริง โดย ใช้เครื่องมือทางคุณภาพตามหลักการวิเคราะห์ของระบบการผลิตแบบโตโยต้า (Toyota Production System) คือ WhyWhy Analysis ซึ่งจะช่วยในการตั้งคำถามไปเรื่อยๆ เพื่อให้ได้คำตอบที่เป็นรากเหง้าสาเหตุของปัญหาที่แท้จริง จากนั้นจึงนำ สาเหตุปัญหาที่ได้นั้นมาวางแผนในการปรับปรุงต่อไป ยกตัวอย่างเช่น นำกระบวนการประกอบชิ้นส่วนย่อย 2 มาวิเคราะห์ หาสาเหตุของปัญหา ดังรูปที่ 5

\begin{tabular}{|c|l|l|}
\hline Why & \multicolumn{1}{|c|}{ คำถาม } & \multicolumn{1}{c|}{ คำตอบ } \\
\hline Why 1 & $\begin{array}{l}\text { ทำไมถึงรองานจากกระบวนการ } \\
\text { ก่อนหน้า }\end{array}$ & $\begin{array}{l}\text { เพราะกระบวนการประกอบชิ้นส่วนย่อย1 ยังไม่ } \\
\text { สงชิ้นงานมาให้ }\end{array}$ \\
\hline Why 2 & ทำไมยังไม่ส่งชิ้นงานมาให้ & เพราะต้องผลิตให้ครบทั้ง 3 ชนิดแล้วจัดส่ง \\
\hline Why 3 & $\begin{array}{l}\text { ทำไมถึงต้องผลิตให้ครบทั้ง } 3 \\
\text { ชนิด แล้วจัดสง }\end{array}$ & เพราะเป็นตามมาตรฐานการทำงานที่กำหนดไว้ \\
\hline Why 4 & $\begin{array}{l}\text { ทำไมมาตรฐานการทำงาน } \\
\text { กำหนดให้สงรอบละ } 3 \text { ชนิด }\end{array}$ & เพราะมีระยะทางระหว่างกระบวนการไกล \\
\hline Why 5 & $\begin{array}{l}\text { ทำไมระยะทางระหว่าง } \\
\text { กระบวนการ่ไกล }\end{array}$ & เพราะมีการออกแบบผังการทำงานที่ไม่เหมาะสม \\
\hline
\end{tabular}

รูปที่ 9 ตัวอย่างการใช้เทคนิคการตั้งคำถาม Why-Why Analysis เพื่อหาความสูญเปล่าของกระบวนการประกอบชิ้น ส่วนย่อย2

จากตัวอย่างที่กล่าวข้างต้น การใช้เทคนิคการตั้งคำถาม Why-Why Analysis พบว่าความสูญเปล่าจากการรองานจาก กระบวนการก่อนหน้าเกิดจากการวางแผนผังการทำงานที่ไม่เหมาะสม ดังนั้นนำสาเหตุที่ได้ไปวางแผนการปรับปรุงต่อไป

\section{4. การวางแผนและดำเนินการปรับปรุงแก้ไขปัญหา}

1. รวบรวมแนวทางการแก้ไขปัญหาจากทฤษฎีและงานวิจัยที่เกี่ยวข้องในเรื่องเกี่ยวกับการปรับปรุงประสิทธิภาพ กระบวนการผลิต และจากการระดมสมองของทีมงาน เพื่อนำมาประยุกต์ใช้สำหรับการปรับปรุงแก้ไขปัญหานี้ 
2. จัดประชุมกับผู้บริหารโรงงานเพื่อให้ทราบถึงแนวทางในการแก้ไขปรับปรุงต่างๆ โดยการใช้หลักการ $E C R S$ (การกำจัด, การรวมกัน, การจัดใหม่, ทำให้ง่ายขึ้น) เข้าไปดำเนินการแก้ไข

2.1. ปรับเปลี่ยนผังกระบวนการผลิตจากการผลิตแบบงวด (Batch Production Process) เป็นการผลิตแบบไหลทีละ ชิ้น (One-piece Flow Process) โดยการจัดวางแผนผังของเครื่องจักรและอุปกรณ์ต่างๆ ให้เป็นแบบการไหลอย่าง ต่อเนื่องตั้งแต่ต้นกระบวนการจนจบกระบวนการ เพื่อลดเวลาของความสูญเปล่าในการขนส่งระหว่างกระบวนการ ลด การเคลื่อนไหวของพนักงานที่ไม่จำเป็น แล้วส่งผลทำให้พื้นที่ของสายการผลิตลดลงอีกด้วย แสดงเป็นแผนภาพ กระบวนการมาตรฐานหลังการปรับปรุงดังรูปที่ 10 และ 11

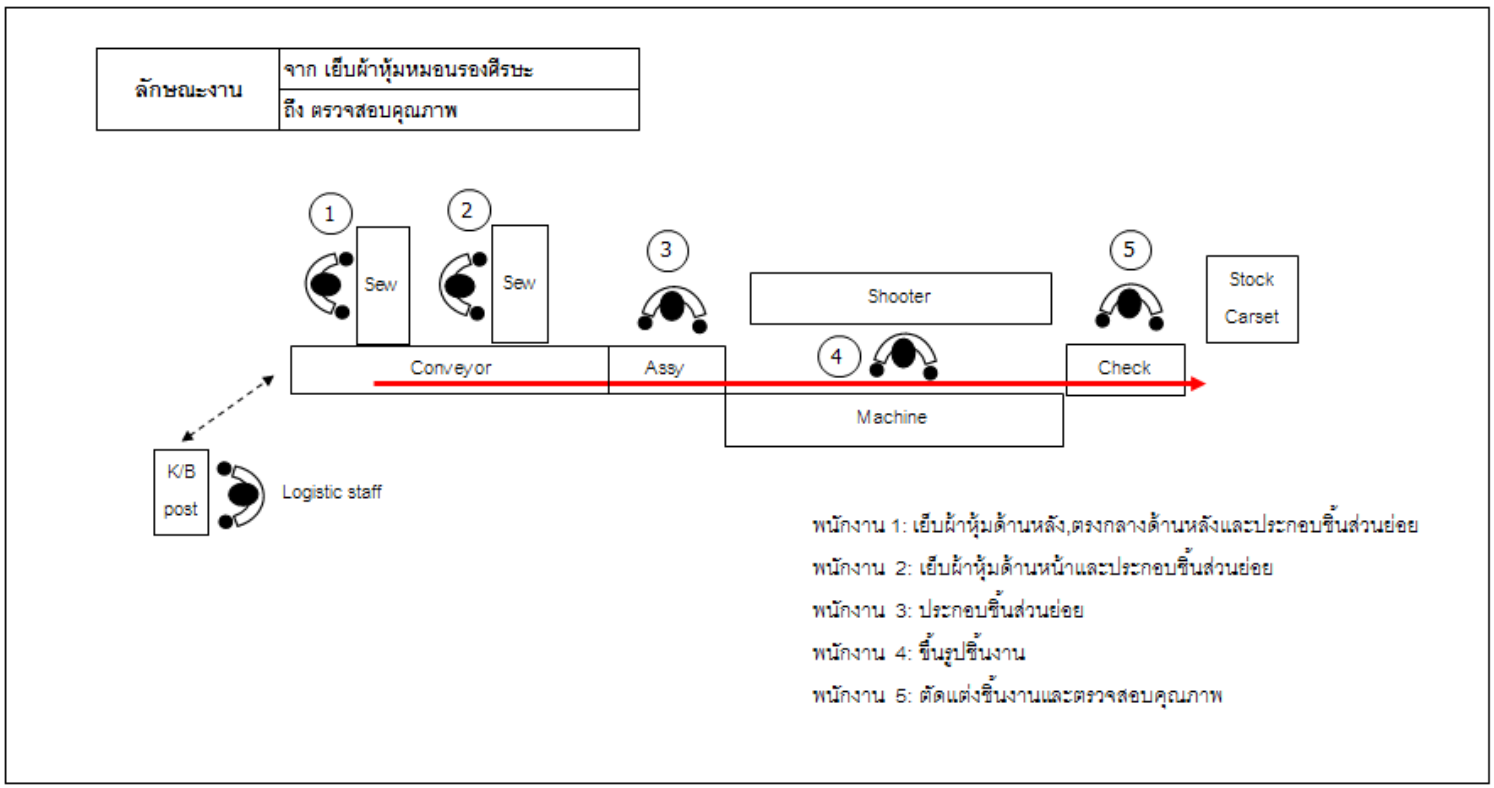

รูปที่ 10 แผนภาพกระบวนการมาตรฐานของกระบวนการผลิตหมอนรองศีรษะหลังการปรับปรุง

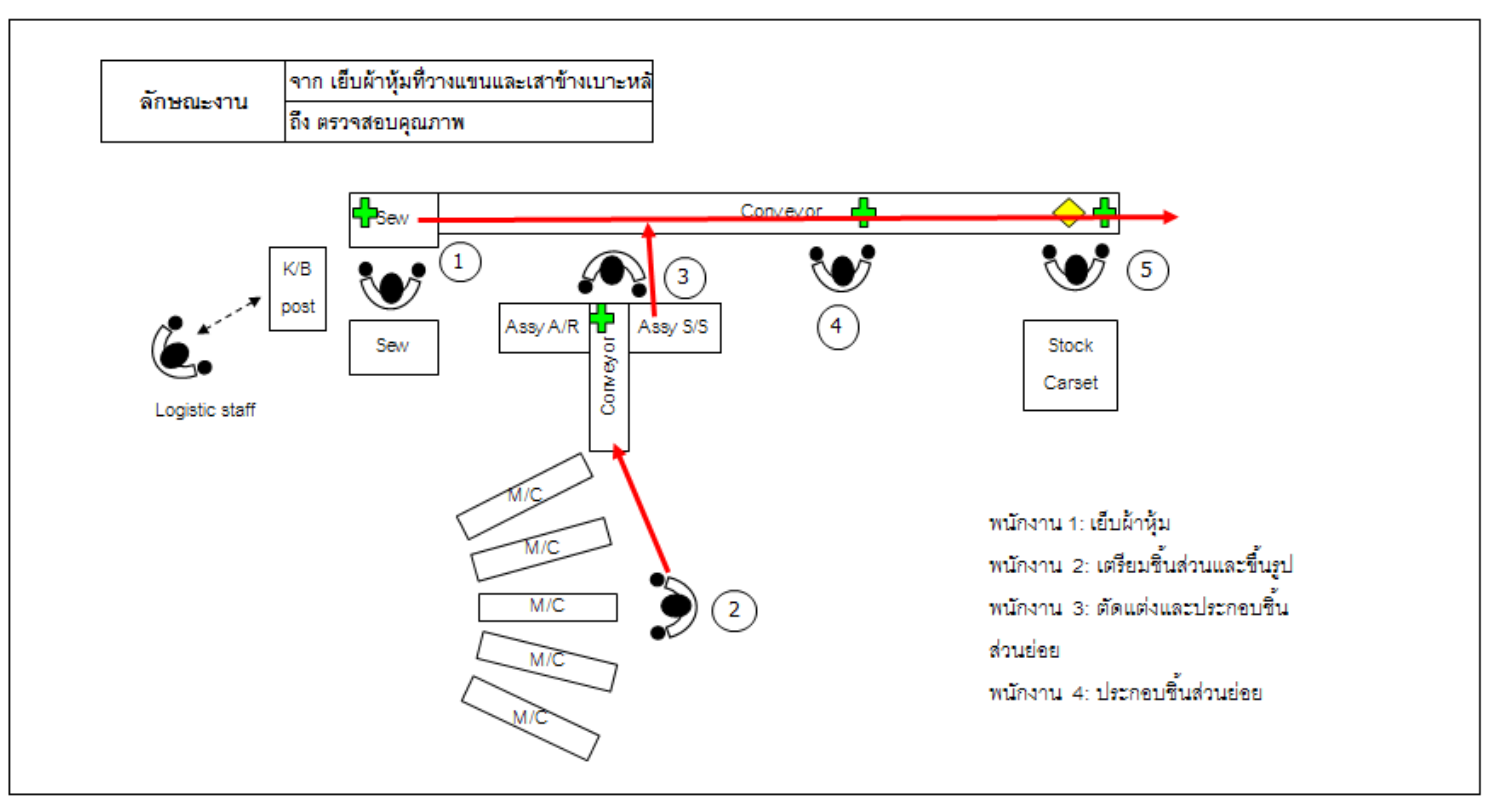

รูปที่ 11 แผนภาพกระบวนการมาตรฐานของกระบวนการผลิตที่วางแขนและเสาข้างเบาะหลังหลังการปรับปรุง 
2.2. ทำการจัดภาระงานของแต่ละกระบวนการใหม่เพื่อให้เกิดความสมดุลและเหมาะสมของกระบวนการผลิตโดยการ พิจารณาการเพิ่มขั้นตอนการทำงานให้กับกระบวนการที่มีช่องว่างระหว่างรอบเวลาในการทำงานกับรอบเวลาในการ ผลิตเหลืออยู่ ซึ่งจะทำให้สามารถลดจำนวนพนักงานที่เกินความจำเป็นและส่งผลทำให้ลดต้นทุนในการผลิตเมื่อปรับ เพิ่มเป็น 2 กะการจัดภาระงานของแต่ละกระบวนการเริ่มจากนำข้อมูลยอดการสั่งซื้อสูงที่สุดดังรูปที่ 1 และ 2 คำนวณหารอบเวลาในการผลิตที่เหมาะสมเพื่อเป็นเป้าหมายในการจัดสมดุลงานของแต่ละกระบวนการโดยเพิ่มเวลา การทำงานเป็น 2 กะ และประสิทธิภาพเป้าหมายของโรงงานที่ 95 เปอร์เซ็นต์ ดังต่อไปนี้

รอบเวลาในการผลิตหมอนรองศีรษะ

$$
\begin{aligned}
& =594,000 \times 2 \text { วินาที } / 6,273 \text { ชุดต่อคันรถ } \times 95 \% \\
& =179 \text { วินาที } / \text { ชุดต่อคันรถ }
\end{aligned}
$$

รอบเวลาในการผลิตที่วางแขนและเสาข้างเบาะหลัง

$$
\begin{aligned}
& =594,000 \times 2 \text { วินาที / 2,356 ชุดต่อคันรถ } \times 95 \% \\
& =479 \text { วินาที / ชุดต่อคันรถ }
\end{aligned}
$$

2.3. ทำการปรับปรุงอุปกรณ์ต่างๆ เพื่อช่วยให้การทำงานของพนักงานสะดวกมากขึ้นโดยพิจารณาจากการเคลื่อนไหว ของพนักงานให้น้อยที่สุด ซึ่งจะทำให้ลดเวลาความสูญเปล่าของการเคลื่อนไหว เช่น การเพิ่มสายพานลำเลียงชิ้นงาน การจัดวางสายพานลำเลียงให้อยู่ที่หน้าตำแหน่งการทำงาน และอื่นๆ

3. ดำเนินการแก้ไขปรับปรุงกระบวนการผลิต

4. ทำการเก็บข้อมูลผลหลังจากการนำแนวทางการปรับปรุงแก้ไขไปใช้โดยใช้วิธีการเก็บข้อมูลจริงที่ได้หลังจากการปรับปรุง ประกอบด้วย รอบเวลาในการทำงาน จำนวนกระบวนการ จำนวนพนักงาน จำนวนขั้นตอนการทำงาน และประสิทธิภาพของ กระบวนการผลิต เพื่อจะนำข้อมูลไปเปรียบเทียบก่อนและหลังการปรับปรุง

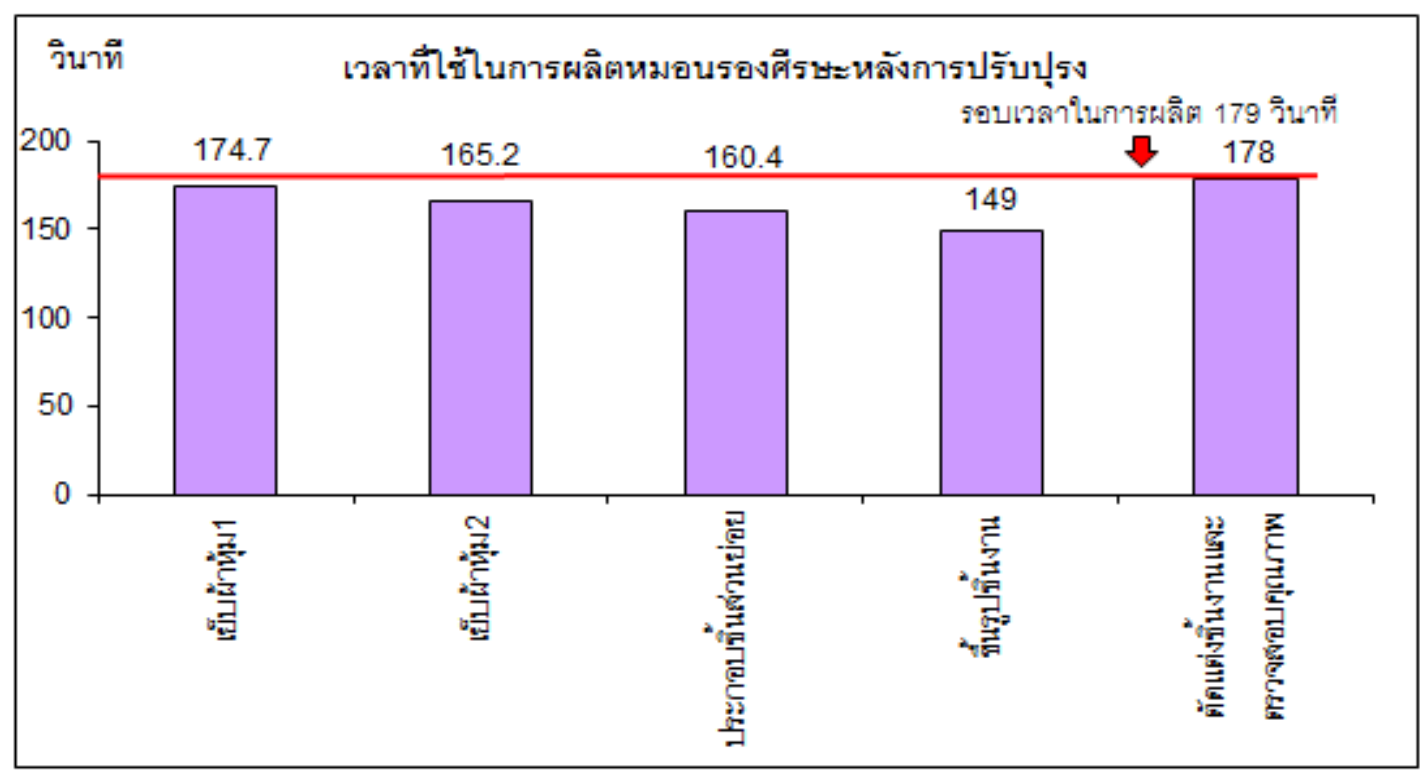

รูปที่ 12 รอบเวลาในการทำงานของกระบวนการผลิตหมอนรองศีรษะหลังการปรับปรุง 
จากกราฟรูปที่ 12 การปรับปรุงรอบเวลาในการทำงานของหมอนรองศีรษะเท่ากับ 178 วินาที ซึ่งมีกำลังการผลิตเหลือ มากกว่าเวลาที่เป็นเป้าหมาย จากนั้นคำนวณหาประสิทธิภาพของกระบวนการผลิตเท่ากับ 93.0 เปอร์เซ็นต์ เพิ่มขึ้นจาก 78.7 เปอร์เซ็นต์ แล้วยังสามารถลดจำนวนพนักงานได้อีก 2 คน

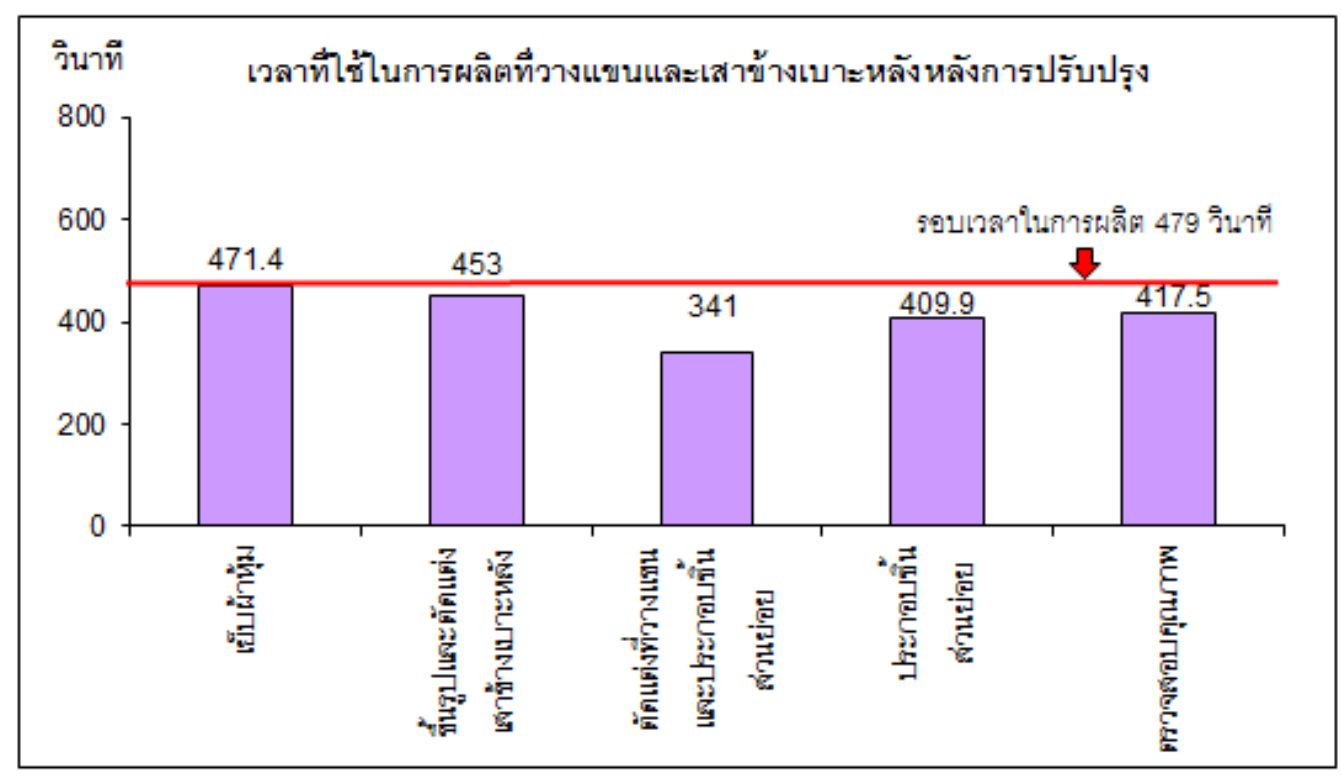

รูปที่ 13 รอบเวลาในการทำงานของกระบวนการผลิตที่วางแขนและเสาข้างเบาะหลังหลังการปรับปรุง

จากกราฟรูปที่ 13 การปรับปรุงรอบเวลาในการทำงานของหมอนรองศีรษะเท่ากับ 471.4 วินาที ซึ่งมีกำลังการผลิตเหลือ มากกว่าเวลาที่เป็นเป้าหมาย จากนั้นคำนวณหาประสิทธิภาพของกระบวนการผลิตเท่ากับ 88.8 เปอร์เซ็นต์ เพิ่มขึ้นจาก 75.2 เปอร์เซ็นต์ แล้วยังสามารถลดจำนวนพนักงานได้อีก 1 คน

\section{5. ผลการปรับปรุง}

หลังจากการปรับปรุงสายการผลิตโดยใช้หลักการ $E C R S$ เข้าไปกำจัดความสูญเปล่าที่เกิดขึ้นในกระบวนการผลิต จัดผังการ ทำงานใหม่แล้วรวมงานย่อยของกระบวนการที่สามารถเพิ่มงานให้ได้เข้าด้วยกัน จากนั้นจัดสมดุลการทำงานใหม่ให้แต่ละ กระบวนการพร้อมทั้งจัดองค์ประกอบและอุปกรณ์ต่างๆ ในการทำงานเพื่อช่วยให้พนักงานทำงานได้สะดวกมากขึ้นและลด การเมื่อยล้าในการทำงาน ซึ่งทำให้ได้ผลการปรับปรุงดังต่อไปนี้

1. สามารถเพิ่มกำลังการผลิตเป็น 2 กะ โดยใช้รอบเวลาในการทำงานเท่ากับ 178 วินาที ผลิตได้ 6,273 ชุดต่อคันรถ สำหรับกระบวนการผลิตหมองรองศีรษะ และรอบเวลาในการทำงานเท่ากับ 471.4 วินาที ผลิตได้ 2.356 ชุดต่อคันรถ สำหรับ กระบวนการผลิตที่วางแขนและเสาข้างเบาะหลัง ดังนั้นสามารถรองรับต่อยอดสั่งซื้อจากลูกค้าที่จะเพิ่มขึ้นในอีก 2 ปี ตาม นโยบายผู้บริหารเพื่อให้กำลังการผลิตเพิ่มขึ้นได้ตามเป้าหมาย

2. ปรับปรุงสายการผลิตเปลี่ยนจากการผลิตแบบงวดให้เป็นการผลิตแบบการไหลอย่างต่อเนื่องหรือการไหลทีละชิ้นย้าย ตำแหน่งการวางเครื่องจักรและอุปกรณ์ใหม่เพื่อลดระยะทางระหว่างระบวนการ ทำให้พื้นที่ในสายการผลิตลดลง 103.30 ตารางเมตร จาก 452.05 ตารางเมตร คิดเป็น 22.85 เปอร์เซ็นต์ แล้วสามารถนำพื้นที่ใช้สอยไปใช้กับสายการผลิตอื่นที่กำลัง ขาดแคลนพื้นที่ในการขยายการผลิต 
3. ผลจากการจัดสมดุลภาระงานระหว่างพนักงานกับกระบวนการทำงานทำให้มีจำนวนพนักงานในกระบวนการผลิต หมอนรองศีรษะลดลง 2 คน และกระบวนการผลิตที่วางแขนและเสาข้างเบาะหลังลดลง 1 คน ทางโรงงานมีนโยบายการเพิ่ม การผลิตเป็น 2 กะ ทำให้สามารถลดจำนวนพนักงานได้ถึง 6 คน จาก 26 คน ทำให้ต้นทุนด้านแรงงานของสายการผลิตลดลง สามารถเปรียบเทียบต้นทุนค่าแรงงานก่อนและหลังการปรับปรุงดังนี้

$\begin{aligned} \text { ต้นทุนค่าแรงของพนักงานก่อนการปรับปรุง } & =\quad \text { จำนวนวันทำงาน } \times \text { จำนวนพนักงาน } \times \text { ค่าแรงพนักงาน } \\ & =22 \text { วัน ต่อเดือน } \times 26 \text { คน } \times 280 \text { บาท ต่อวัน } \\ & =160,160 \text { บาท ต่อเดือน } \\ \text { ต้นทุนค่าแรงของพนักงานหลังการปรับปรุง } & =22 \text { วัน ต่อเดือน } \times 20 \text { คน } \times 280 \text { บาท ต่อวัน } \\ & =123,200 \text { บาท ต่อเดือน }\end{aligned}$

4. ผลจากการปรับปรุงสายการผลิตโดยหลักการ ECRS ทำให้ประสิทธิภาพของกระบวนการผลิตหมอนรองศีรษะเพิ่มขึ้น จาก 78.7 เปอร์เซ็นต์ เป็น 93 เปอร์เซ็นต์ และประสิทธิภาพของกระบวนการผลิตที่วางแขนและเสาข้างเบาะหลังเพิ่มขึ้นจาก 75.2 เปอร์เซ็นต์ เป็น 88.8 เปอร์เซ็นต์ ทำให้สายการผลิตมีประสิทธิภาพมากขึ้นและสามารถรองรับกับยอดการสั่งซื้อที่สูงสุด ได้

\section{6. สรุปผลการวิจัยและข้อเสนอแนะ}

การปรับปรุงกำลังการผลิตของสายการผลิตชิ้นส่วนเบาะที่นั่งรถยนต์ด้วยแนวคิดระบบการผลิตแบบโตโยต้าเพื่อที่จะรองรับ ยอดการสั่งซื้อที่จะเพิ่มขึ้นเกือบเท่าตัวในอีก 2 ปี ข้างหน้า จากการดำเนินงานได้ปรับเปลี่ยนกระบวนการผลิตที่ไม่ต่อเนื่องให้ เป็นการไหลทีละชิ้นโดยการกำจัดความสูญเปล่าในกระบวนการ ปรับปรุงแผนผังการทำงาน ปรับปรุงสมดุลภาระงานของ พนักงานแต่ละคนในกระบวนการทำงานใหม่ แล้วจัดทำมาตรฐานการทำงานใหม่ให้กับสายการผลิต จากการปรับปรุงยังคง ต้องปรับเพิ่มชั่วโมงการทำงานการผลิตเป็น 2 กะ ประสิทธิภาพของกระบวนการผลิตหมอนรองศีรษะเพิ่มขึ้นจาก 78.7 เปอร์เซ็นต์ เป็น 93 เปอร์เซ็นต์ และประสิทธิภาพของกระบวนการผลิตที่วางแขนและเสาข้างเบาะหลังเพิ่มขึ้นจาก 75.2 เปอร์เซ็นต์ เป็น 88.8 เปอร์เซ็นต์ แล้วพื้นที่ในสายการผลิตลดลง 103.30 ตารางเมตร จาก 452.05 ตารางเมตร คิดเป็น 22.85 เปอร์เซ็นต์ พนักงานในกระบวนการผลิตลดลง 6 คน จาก 26 คน ส่งผลทำให้ต้นทุนค่าแรงงานลดลงจาก 160,160 บาท ต่อเดือน เหลือเพียง 123,200 บาท ต่อเดือน ผลจากการปรับปรุงได้บรรลุตามเป้าหมายของโรงงานที่ต้องการกำลังการ ผลิตเพิ่มขึ้นเพื่อรองรับความต้องการของลูกค้าพร้อมทั้งสามารถลดต้นทุนในการผลิตได้อีกด้วย

ข้อเสนอแนะในการศึกษาครั้งต่อไป การปรับปรุงประสิทธิภาพการผลิตยังสามารถดำเนินการศึกษาเพิ่มเติมได้ด้วย การศึกษากระบวนการทำงานอย่างละเอียดเพื่อปรับปรุงประสิทธิภาพแต่ละขั้นตอนของการผลิต ด้วยการศึกษาวิธีการ ทำงาน สถานที่ทำงาน การใช้เครื่องมือที่มีประสิทธิภาพกว่ามาช่วยในการทำงาน เป็นต้น 


\section{บรรณานุกรม}

[1] J. K. Liker and D. Meier, The Toyota Way. New York: McGraw-Hill, 2004.

[2] D. Roy and D. Khan, "Assembly line Balancing to minimize balancing loss and system loss," J. Ind. Eng. Int., vol. 6, no. 11, pp. 1-5, Spring, 2010.

[3] ธวัชชัย สุวรรณบุตรวิภา, กลยุทธ์การจัดการสมดุลสายการผลิตให้มีประสิทธิภาพ. กรุงเทพมหานคร: สถาบันอินเทลลิ ฟิค, 2542.

[4] C. M. Fiallo and G. Howell, "Using production system design and Takt time to improve project performance," presented at the 20th Conference of the International Group for Lean Construction, 2012.

[5] อดิศักดิ์ แป๊ะพุฒ, "การเพิ่มผลิตภาพในกระบวนการผลิตของโรงงานประกอบชิ้นส่วนอิเล็กทรอนิกส์," วิทยานิพนธ์ ปริญญามหาบัณฑิต ภาควิชาวิศวกรรมอุตสาหการ คณะวิศวกรรมศาสตร์ จุฬาลงกรณ์มหาวิทยาลัย, 2553.

[6] ปฐมพงษ์ หอมศรี, อัมพิกา ไกรฤทธิ์, และ ปรณัฐ วิสุวรรณ, "การประยุกต์ใช้ระบบโตโยต้าในสายการผลิตของ โรงงานผลิตถังน้ำมันรถยนต์," presented at การประชุมวิชาการข่ายงานวิศวกรรมอุตสาหการประจำปี $2554,20-21$ ตุลาคม 2554 , หน้า 90-104.

[7] มังกร โรจน์ประภากร, ขจัด Muda, พิมพ์ครั้งที่ 4. กรุงเทพฯ: สมาคมส่งเสริมเทคโนโลยี (ไทย-ญี่ปุ่น), 2552, หน้า 118$126,145-147$.

[8] ภาวิณี อาจปรุ, "การลดเวลาสูญเปล่าในกระบวนการผลิตผลิตภัณฑ์เบรกเกอร์," วิทยานิพนธ์ปริญญามหาบัณฑิต ภาควิชาวิศวกรรมอุตสาหการ คณะวิศวกรรมศาสตร์ จุฬาลงกรณ์มหาวิทยาลัย, 2551. 
